Crime victims' rights commissioners: public interest entities in a regulatory regime

Robyn L. Holder ${ }^{1}$ and Tyrone Kirchengast ${ }^{2}$

This is a PRE-PUBLICATION version accepted for publication in the International Journal of Comparative and Applied Criminal Justice. For citations, please refer to the published article at https://doi.org/10.1080/01924036.2020.1719527

Correspondence concerning this article should be addressed to Robyn Holder, Griffith Criminology Institute, Mt Gravatt Campus, Griffith University, 176 Messines Ridge Road, Mt Gravatt, Queensland 4122, Australia. E-mail: r.holder@griffith.edu.au

${ }^{1}$ Griffith University, Brisbane, Queensland, AUSTRALIA

${ }^{2}$ Sydney University, Sydney, New South Wales, AUSTRALIA 


\title{
Victims' rights commissioners: public interest entities in a regulatory regime
}

\begin{abstract}
The legal force of crime victims' rights is ambiguous: are they service standards or legal rights? This question has created confusion about the nature of compliance and bifurcates the enforcement mechanism as administrative or legal. Regulatory analysis creates a wider lens to this debate. In this article, we conceive victims' rights charters as part of a regulatory regime designed to influence the conduct of state agencies in discharging their functions. Rights compliance and enforcement as a regulatory challenge provides a framework for systematic analysis of regulatory instruments, tools and strategies chosen by key actors. We use a case study of statutory Australian crime victims' rights commissioners to illustrate the implications of these choices. We suggest that clearer articulation of the techniques of compliance show the coexistence of administrative and legal sanctioning. Our argument turns attention to the duties imposed on public institutions of criminal justice and their accountability.
\end{abstract}

\section{KEYWORDS}

Crime victims' rights; regulation; victims' commissioner; compliance 


\section{Victims' rights commissioners: public interest entities in a regulatory regime}

\section{Introduction}

Over the past three decades, many jurisdictions have introduced standards, called victims' 'rights' or victim charters, for criminal justice institutions to guide their treatment of crime victims. Victims' rights scholarship has examined the scope of these guidelines and the extent to which they create a platform for people as crime victims to participate meaningfully in legal proceedings (Davis \& Mulford, 2008; Doak, Henham \& Mitchell, 2009; Kirchengast, 2017; Manikis, 2012). The legal force of the guidelines is ambiguous: are they service standards or legal rights? This in turn has created confusion about the nature of compliance and bifurcates the enforcement mechanism as administrative or legal. It leaves open questions about the role and impact of victims' 'rights'. In this article we use regulatory analysis to apply a wider lens to this debate. We conceive victims' rights charters as part of a regulatory regime designed to influence the conduct of state agencies in discharging their functions. Approaching rights compliance and enforcement as a regulatory challenge provides a framework for systematic analysis of regulatory instruments, tools and strategies chosen by key actors. We use a case study of Australian victims' rights commissioners; statutory entities established to promote and protect the interests of crime victims to illustrate the implications of these choices and to identify soft to hard regulatory forms. Our argument turns attention to the duties that rights impose on public institutions of criminal justice. As a way forward, we develop an exemplar victims' rights compliance strategy that shows the coexistence of administrative and legal sanctioning. 


\section{Regulation and compliance}

Regulatory scholarship is vast and its meanings and implications are much debated. ${ }^{1}$ At its simplest, regulation "influenc[es] the flow of events" (Parker \& Braithwaite, 2003, p. 119). The actors involved and the range of regulatory activities are context sensitive. We develop our regulatory analysis of victims' rights commissioners later in this article but, to assist readers unfamiliar with it, introduce some key ideas and terms and how we use them. Regulation poses that,

... any control system in art or nature must by definition contain a minimum of the three components ... There must be some capacity for standard-setting, to allow a distinction to be made between more or less preferred states of the system. There must also be some capacity for information-gathering or monitoring to produce knowledge about current or changing states of the system. On top of that must be some capacity for behaviour-modification to change the state of the system (italics in original). (Hood, Rothstein, \& Baldwin, 2001, p. 23)

In this article, the criminal justice system is the focus of a regulatory "regime" involving a “complex of institutional geography, rules, practice, and animating ideas that are associated with the regulation of a particular risk or hazard" (Hood et al., 2001, p. 9). ${ }^{2}$ The geography of criminal justice includes institutions of police, prosecution, courts and corrections. One

\footnotetext{
${ }^{1}$ In our discussion we draw heavily on the text and materials brought together in Bronwen Morgan and Karen Yeung's book, An introduction to law and regulation (Cambridge University Press, 2007).

${ }^{2}$ Another term encompassing the sector or domain coverage is 'regulatory space' (Hancher \& Moran, 1989).
} 
animating idea central to criminal justice, especially for due process and access to justice, is fairness. Thus, the risk or hazard is the variable application or absence of fairness. Civilians in criminal justice are categorised as accused or victim but, in a regulatory analysis, are also understood as citizens, consumers, taxpayers, and as social and political agents. Different criteria for fairness - such as equality, equity or deservingness - are emphasised from different of these standpoints (Sen, 2009).

Various legal rules govern the application of fairness to citizens accused of crimes. ${ }^{3} \mathrm{~A}$ victims' charter is a set of minimum rules or standards applying fairness to citizens as victims of, and possibly a witness to, crimes. The rules are to influence the behaviour of criminal justice institutions and professionals towards citizens as victim in their engagements with the administration of justice. We describe these institutions as 'regulated entities'. Further, governments have put in place rights-promoting entities as 'regulators' to shape, nurture, and sustain criminal justice institutions' adherence to victims' charter standards. These regulators or regulatory bodies use a variety of methods based on information gathered in pursuit of that goal. These 'regulatory instruments' and 'regulatory tools' are largely, but not exclusively, pre-selected by governments in their design of the regulator. The instruments and tools are adopted in varying formal and informal ways by regulatory bodies to produce behaviour acceptable to the preferred standards of fairness the legislature has enacted.

\footnotetext{
${ }^{3}$ For the United Kingdom (UK) see, Emmerson et al. ( $3^{\text {rd }}$ Ed) (2012). Human rights and criminal justice. London, Sweet \& Maxwell; for the US see, Bodenhamer (2008). Fair trial: Rights of the accused in American history. OUP USA; and for Australia see, Bronitt \& McSherry (2017). Principles of criminal law (4 $4^{\text {th }}$ Ed.). Sydney, Australia: Thomson Reuters, Lawbook Company.
} 
Design of the regulatory regime is not the only concern for regulatory scholarship. It is also concerned with compliance. The term has surface simplicity but has different associations. One is that compliance is a matter of obeying the rules or standards set. Another equates compliance with a formal legal process that follows an alleged breach of a standard and which is capable of imposing a sanction and/or mandating a specific required behaviour. Summarising debates, Hutter argues that compliance is as much "a process as an event." "Regulatory officials", she writes "may regard compliance both as a matter of instant conformity and an open-ended and long-term process which may take several years to attain" (Hutter, 1997, p. 12). Regulation deals with messy, dynamic interactions. It is relational as well as transactional, where rules are in any case often indeterminate and open to interpretation (Black, 1997). Compliance is as much about informal practice as formal process.

Such ambiguity is small comfort to citizens who believe their individual rights have been violated. While victims' rights may be decried as “illusory” (Beloof, 2005; Kirchengast, 2016a), citizens may reasonably assume both the duty of regulated entities of police, prosecution, courts and corrections to comply with legislatively specified standards and, should they not, the citizen has some way of requiring compliance; that there will be fair review and possible enforcement of the right at issue. Thus, we conceive of enforcement as a component of compliance.

Given the central place of implementation and compliance in the regulation literature, it is surprising that victims' rights scholars have not engaged with it more frequently. ${ }^{4}$ Addressing

\footnotetext{
${ }^{4}$ Other rights-promoting reform literature has done so. Australian examples include a review that promoted a regulatory model for the Human Rights and Equal Opportunities Commission
} 
this gap, we consider both design and compliance strategies in this article. We discuss victims' rights commissioners as a regulator. We examine the various tools in their regulatory toolkit. Rights commissioners are a design choice made by governments. Their functions and powers in turn direct the strategies they deploy to produce and monitor compliance with victim charter standards by the regulated entities of police, prosecution, courts, and corrections. We simplify our analysis of Australian victims' rights commissioners by mainly focusing on their performance as regulators of public prosecutors.

One clear choice made by governments in Australia in creating a regulatory regime governing victim charters is to specify that the standards are not legal rights notwithstanding the use of rights language in statutes and public discourse (Kirchengast, 2016b). The content of the charters generally lists 'rights' to respectful treatment, access to information, and adequate notification of case progression amongst others. In truth, these are "legitimate expectations' of citizens" interacting with public authorities (Thomas, 2000, p. 1; see also Shapland, 2000, pp. 147-64). Nonetheless, in this article we use the terms 'standards' and 'rights' interchangeably. We first expand on this context in a brief outline of the emergence of victims' charters before turning to set out some of the key terms and approaches in regulatory analysis.

\section{Crime victims and criminal justice}

Presently, crime victims are dealt with in dispersed ways whether in an individual or public policy context. Therefore, it is important to know how a victims' rights regulatory regime

in Victoria (Gardner, 2008, pp 43-47); and analysis of the regulatory mechanisms in federal anti-discrimination law (Smith, 2006). 
emerges. Its history and context are central to understanding the contours and content of a regime in its present form. A victims' rights regime has two basic origin stories within common law countries. The first is a centuries long story where initiating prosecution of the vast bulk of criminal conduct was the responsibility of private individuals (Langbein, 2003; Kirchengast, 2006); a feature of English law that continued as criminal justice developed in colonial settler countries such as the United States (US) (Cardenas, 1986), Canada (Stenning, 1986) and Australia (Woods, 2002). These histories show that the institutional geography of criminal justice has not always looked as it does today. The institution of public prosecution is a relatively recent innovation notwithstanding the longer history to the public nature of the criminal law (Hetherington, 1989). It is a Weberian success story of the centralising and modernising state. A dominant prosecution authority creates efficiencies in the use of public resources, filters and smooths out the diverse experiences' citizen-victims bring to criminal justice and standardises a state perspective on the public interest (Rock, 2004). Nonetheless, this "competition for control of access to the legal resources inherited from the past" (Bourdieu, 1987, p. 817) has resulted in a state monopoly. Citizen-victims who seek adjudication of alleged criminal conduct have no realistic access to criminal courts other than through the public prosecutor.

The second story is more recent. Researchers examining the contemporary conduct of police and prosecutors in different legal systems have consistently found evidence of abuse of power in persisting discourtesies, inadequate provision of information, and limited assistance and consultation with crime victims (Fundamental Rights Agency [FRA], 2019; Sebba, 1996; Shapland, Willmore \& Duff, 1985). These procedural variables, along with inconsistent case outcomes, are associated with victim dissatisfaction with criminal justice (Laxminarayan, Bosman, Porter \& Sosa, 2013; Whitehead, 2001). Those victimised by particular types of 
offending have especially poor experiences with criminal justice: both child and adult sexual assault victims find giving evidence traumatic and difficult, ${ }^{5}$ victims of domestic violence say their concerns and safety are not taken seriously (Buzawa \& Buzawa, 2003), victims of crimes of bias or hate find their experiences misunderstood (Hall, 2005), and families of homicide victims feel marginalised by the process (Englebrecht, Mason, \& Adams, 2014).

In combination, these two stories say a couple of things: overwhelming dominance of state entities enables a system for system-convenience, and, with "capacity and authority to act unbound" (Holder, 2018a, p. 25), facilitates oppressive practices against citizens, whether accused or victim. In this context, regulation protects the public from an abuse of monopoly power (Ogus, 2004).

A regulatory response to the situation appeared at an international level with the 1985 Declaration of Basic Principles of Justice for Victims of Crime and Abuse of Power [herein the Victims' Declaration]. The Victims' Declaration was adopted by the General Assembly of the United Nations (UN) as a set of standards for countries to adopt for their criminal justice institutions. Although General Assembly declarations are non-binding, they "carry the weight of world opinion as well as the moral authority of the world community" (Brienen \& Hoegen, 2000, p. 10). The Victims' Declaration was unanimously adopted by countries in the General Assembly and has since been adopted into the laws of many countries including members of the European Union. In federal systems of the US, Australia, and Canada, the Victims Declaration has been incorporated within the federal criminal jurisdiction and at state

\footnotetext{
${ }^{5}$ Issues that were extensively canvassed in the Australian Royal Commission into Institutional Responses to Child Sexual Abuse [RCIRCSA] (2017).
} 
or provincial levels. ${ }^{6}$ Supra-national organisations such as the Council of Europe ${ }^{7}$ and the Commonwealth of Nations ${ }^{8}$ also adopted the Victims' Declaration as minimum standards on the rights, support and protection of victims of crime.

However, adoption of a law 'in the books' is different to its implementation 'in action'. An analysis of 22 European countries found the overall rate of implementation of the first 1985 victims' declaration to be “disappointing” (Brienen \& Hoegen, 2000, p. 3), a finding supported by research in the US (Government Accountability Office [GAO], 2008; Hillenbrand \& Smith, 1989; Kirkpatrick, Beatty, \& Howley, 1998), Canada (Manikis, 2012), and Australia (Holder, 2008). Reflecting on these findings, Groenhuijsen argues that implementation of victims" rights charters is actually "a real challenge" for governments

\footnotetext{
${ }^{6}$ All 50 states in the US have some form of victims' rights legislation, and 32 states have constitutional amendments guaranteeing certain rights (Davis, Anderson, Howley, Dorris \& Whitman, 2012, p. 2). At the federal level in Australia, the Standing Committee of Attorneys General (SCAG) adopted a 'national charter of victims' rights' in 1996 (Holder, 2008, pp. 33-34). The first state legislation was 1994 with the passage of a Victims of Crime Act in Western Australia (WA) and separately in the Australian Capital Territory (ACT). In 1988, all Federal, Provincial and Territorial Ministers responsible for justice in Canada agreed a Statement of Principles (Waller, 1996, p. 100).

${ }^{7}$ Recommendation (85)11, later strengthened by the Council Framework Decision 2001/220/JHA, and in turn replaced by Directive 2012/29/EU of the European Parliament and of the Council in October 2012.

${ }^{8}$ In 1985, the Commonwealth of Nations Secretariat produced Guidelines, followed in 2005 by the communiqué of the Commonwealth Senior Law Officers comprising a Statement of Basic Principles of Justice for Victims of Crime.
} 
requiring "drastic changes" to legal and welfare systems in some countries $(2005$, p. 338; and see Groenhuijsen \& Pemberton, 2009). For example, across many European countries there is "paper compliance" and no "purposefully devised properly costed budgets, plans, aims, objectives, targets or timetables for implementation" of victims' charters. ${ }^{9}$ US research similarly identified inadequate funding and training as part of the implementation problem (Davis et al., 2002; OVC, 1998). In addition, researchers have long identified that the 'rights' themselves were diminished by institutional resistance including "the absence of enforcement mechanisms" (Lamborn, 1991).

However, a regulatory regime and the actors within it - including regulator and regulated entity - have a range of capabilities to enforce and comply with the standards they support. At this point we turn to develop further the ideas that regulatory analysis brings to understanding the challenge of influencing institutional behaviour through victims' rights charters. The charters are the standards set by governments in pursuit of the policy goal of better treatment of crime victims by criminal justice institutions. But, assuming the actors in the regulatory regime agree with the policy goal, how are the standards given effect and by what means?

\footnotetext{
${ }^{9}$ The excerpt is an assessment of an expert inspection team examining actions to implement the European Framework Decision on Victims by 10 countries joining the European Union from May 2004 (Phare Report, 2002, p. 53 quoted in Groenhuijsen, 2005, p. 341). Similarly, identifying "tasks" and "budget lines" was found in research on UK criminal justice agencies implementation of victims' rights to be necessary (Shapland, 2000, p. 154).
} 


\section{Regulatory instruments and regulatory tools}

To reprise our introductory remarks, regulation is an effort to "influence socially valuable behaviour which may have adverse side-effects by establishing, monitoring and enforcing legal rules" (Morgan \& Yeung, 2007, p. 3). Of course, rules do not have to be 'legal'. They may be formal or informal. Either way, regulatory instruments and tools are components of a regulatory regime designed to give effect to specified standards. Much regulatory research has explored the actors within pluralistic regulatory ecologies. ${ }^{10}$ This research asks who and what then contribute to which patterns of outcome, and by what means. It examines a wide range of domain from, for example, regulation of private markets (Ogus, 2004), regulation of professions (Wolf, 2017), health and safety (Gunningham \& Grabosky, 1998), and environmental crime (Ayling, 2017). ${ }^{11}$

In whichever domain, a simplified regulatory relationship is between the regulator and regulated entity/ies. Obvious examples of regulator are the US Securities Exchange Commission (SEC) or the Australian Securities and Investments Commission (ASIC). Each has a regulatory relationship with regulated entities such as corporations, banks and other financial institutions. A regulator, as in the SEC and ASIC examples, most often takes some institutional form. A tripartite regulatory framework, however, recognises third parties (Ayres $\&$ Braithwaite, 1992). For our topic, the tripartite regulatory relationship is between victim commissioners as regulator, the public prosecutor as the regulated entity, and the third party

\footnotetext{
${ }^{10}$ We thank Peter Grabosky for this phrase.

${ }^{11}$ The collection edited by Peter Drahos, Regulatory theory: Foundations and applications
} (ANU Press, 2017) provides chapters that discuss regulation across different domain. 
(individual crime victims or representative victim, aggregated groupings of victim or victim activists) (Fig. 1).

Figure 1: The tripartite regulatory relationship in a victims' charter regulatory regime

Regulated entity/ies: police, public prosecutors, courts, \& Regulator: Victims' rights commissioner corrections

Third party: crime victim individuals and/or groups

Before we explore the array of regulatory instruments that governments have put in place to promote victims' charter standards, there are other key concepts to set out; in particular, some idea of the regulatory instrument's scope, the range of tools in the regulator's toolkit, and the strategies they deploy in their regulatory mission. The literature is disorganised with terms instruments, tools and strategies describing similar things. Recognising the problem, Morgan and Yeung (2007) suggest a heuristic categorisation to explore the characteristics of and contexts to instruments and tools that is based on "the underlying 'modality' through which behaviour is sought to be controlled". They offer five broad categories relevant across diverse domain: command, competition, consensus, communication and code (or architecture) (2007, p. 80).

- Command is a 'classic' regulatory model of state-promulgated rules backed by some sanction. 
- Competition usually refers to market mechanisms operable or created between like units whether commercial or non-commercial.

- Consensus modes of regulation are diverse and consent-based.

- Communication-based modes of regulation draw upon norms or normative expectations of behaviour.

- Code refers to various means and mechanisms for designing in desired behaviours or expected standards and designing out undesirable behaviours.

These are descriptions at a high degree of generality. However, how the modalities and associated techniques contribute to a victims' charter regulatory regime are set out in Table 1. Our table summarises a wide range of scholarship and our own work in an analytic matrix considering form, strategy, and tools; and provides examples of how they have been engaged in the regulatory regime of victims' charters. The examples traverse different contexts but are drawn primarily from common law countries.

\section{INSERT TABLE 1 HERE}

The analysis could be read as showing separate and competing approaches to regulating victims' rights standards. This is not the case. The instruments, techniques and tools can be (and usually are) amalgamated and used in different ways to achieve a specific outcome within the overall goal of shaping and directing the conduct of regulated entities under a victims' rights charter. For example, self-regulation (Bardach \& Kagan, 1982) by the office of the public prosecutor may involve internal policy (consensus), creating victim case management templates for use in prosecution files (code), stipulating prosecutor actions (consensus), disciplining staff who fail to comply with these requirements (command), and reporting to government and the public on the annual performance of these requirements (communication). 
Some may also argue that one regulatory technique is gentler and more lenient than another; that 'command' is a more efficient and effective way of shaping behaviour to the desired standards of a victims' charter. Again, this is not necessarily so. A regulatory regime will likely make "tailored use of a graduated scale of regulatory instruments as a means of achieving regulatory goals" (Brewer \& Chang, 2018, p. 9). This idea of graduated regulation is captured in Ayres and Braithwaite's enforcement pyramid with softer consensus and communication approaches at the base, elevating towards hard sanction at the top (Figure 2).

Figure 2: Example of a pyramid of enforcement strategies (Ayres \& Braithwaite, 1992, p. 39)

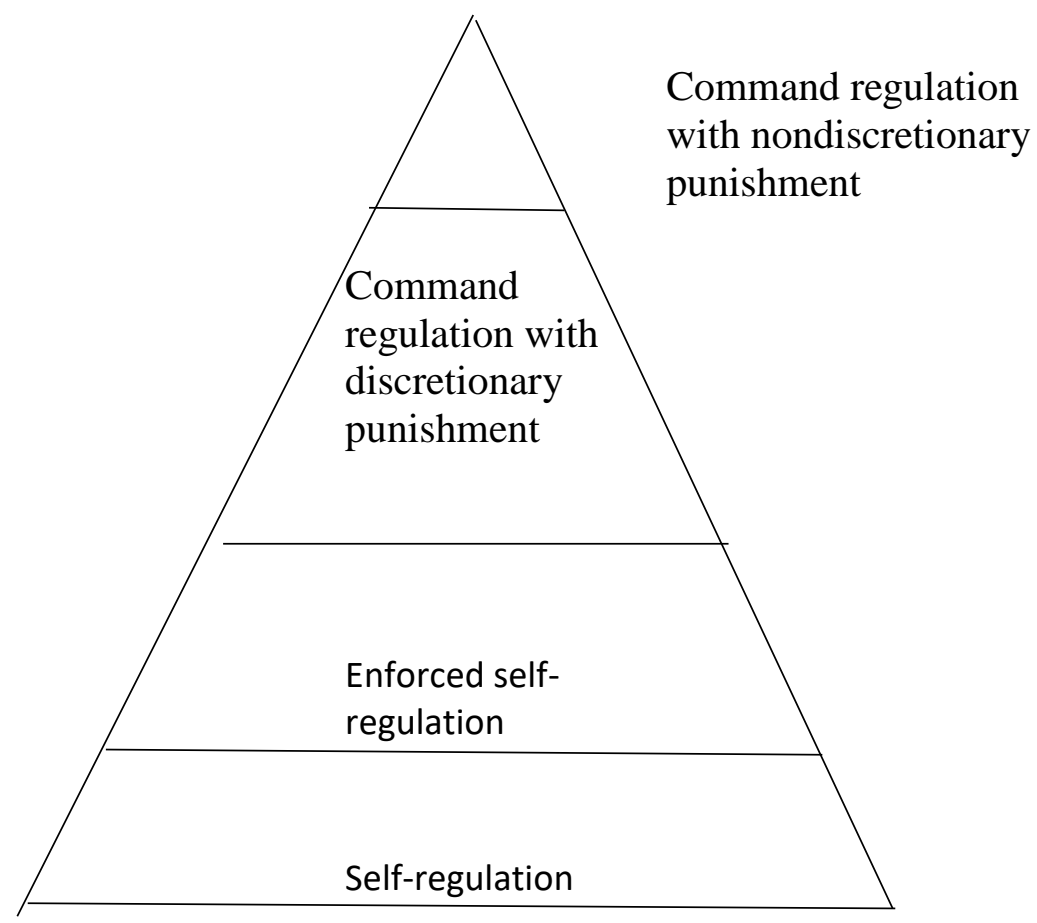

A victims' rights compliance strategy may employ different of these approaches in any given jurisdiction, but compulsion and sanction will be there somewhere in some form, either in the 
background or the foreground. The techniques constitute a 'toolkit'. Thus, we understand compliance is a strategic objective in which design, persuasion, communication, incentives, and enforcement may all be available to support the institutional changes sought under a victims' charter. Thus, compliance and implementation are two sides of the one coin. Which tools are used and when will respond to particularities of the regulatory context (here criminal justice), the nature of the compliance concern(s), and the nature of the regulatory body.

\section{Regulatory bodies}

Regulatory bodies come in different forms with different legal identities. In Australia most regulators, across different domain, are independent statutory authorities; "a public sector entity created by legislation" (Uhrig, 2003, p. 16). In their study of Australian business regulators, Grabosky and Braithwaite (1986) define these as entities established by government, independent of the regulated sector, and with responsibilities to promote desirable behaviours and for acting on undesirable behaviours counter to those determined by the legislature to be in "broader community interests". Regulators administer or work to legislation (p. 3) and often face of an "infinite number of [regulatory] offences" (p. 204). While business regulators such as ASIC or the Australian Competition and Consumer Commission (ACCC) have 'a big stick', they share with less powerful entities such as the Australian Human Rights Commission (AHRC) a range of regulatory techniques and strategies.

Regulators may be 'independent' in different ways and to different extents. They may be independent of executive direction in discharging their functions which are set out legislatively. This is standard for "diagnostic inspectors" (Grabosky \& Braithwaite, 1986, p. 221) in areas such as food safety or fair trading but who remain part of a government 
department. A regulator may also be established as an independent statutory entity where governments wish to place a function 'at arm's length' such as an Auditor-General's Office or an Ombudsman's Office; each of whom are also headed by an independent statutory officer. These offices may act as a general regulator of government functions, services and performance. Others, such as ASIC and the ACCC are external to government and designed to regulate non-government functions. Still others such as a Human Rights Commission, has a specific remit with both government and non-government application. Regulators are watch-dogs.

All these bodies are part of the architecture of state administration but are not of the machinery of government and its bureaucracy. At various times, regulators of different types have been described as "an indispensable aid to accountability", ${ }^{12}$ "political puppets", ${ }^{13}$ and as "gentle" (Grabosky \& Braithwaite, 1986) in their compliance endeavours. These assessments may arise when regulators use some of the powers and strategies in their toolkit (see Table 1) more than others; or when circumstances in the regulatory environment influence them to do so. Nonetheless, a critical feature of independence is having the authority and capacity to communicate its work openly to the wider public, to the legislature, and to other bodies.

${ }^{12}$ The phrase is from Harry Evans, Clerk of the Australian Senate, in prefacing remarks to a Senate Seminar called 'Unchaining the Watch-Dogs'. The proceedings were later published as one of the Papers on Parliament Series: POP7-Unchaining the Watch-Dogs. See https://www.aph.gov.au/About_Parliament/Senate/Powers_practice_n_procedures/pops/pop0 7 retrieved 21 February 2019.

${ }^{13}$ Journalist Verona Burgess writing for The Canberra Times (2002) and cited in Wettenhall (2004, p. 63). 


\section{Victims' rights regulators}

The capacity to speak publicly is a critical power of victims' rights regulators as we shall see. As instruments in a regulatory regime they take different forms. Some of these forms overlap with bodies designed to promote a victims' rights charter and those designed to serve people as crime victims and those designed to assist communication between government and crime victim representatives. Some embody all these functions.

Of course, victims' rights regulators, established within the state architecture, have a different character to those working 'outside the system'. Outsiders may undertake a wide range of work for crime victims including helping them access their 'rights' and justice. They may be funded by government, philanthropy or may function as if a private entity such as a law firm.

Outsiders include community legal centres, advocacy organisations, campaign groups or legal clinics. They may also include the media or professional bodies such as a Law Society. As 'rights advocates', the non-government actors may focus specifically on legal tools and formal enforcement of rules. Exemplars are the National Crime Victim Law Institute's Victims' Rights Clinics previously operating in eight locations across the US (Davis et al, 2012, 2009). Or they may emphasise non-legal advocacy for crime victims as a compliance strategy like Victim Support UK (Rock, 1990) and like most domestic violence advocacy efforts in the US (Davies \& Lyon, 2014).

Formal victims' rights regulatory bodies were established directly from the enactment of victims' charters. In their earliest forms, these were idiosyncratic creatures born of local circumstances. In the UK, legislators prioritised the notion of impartiality for the mechanism to assess complaints from crime victims and nominated the Parliamentary Ombudsman (PO), a body that provides Members of Parliament with an avenue to investigate complaints from 
constituents about issues of maladministration by government entities. The $\mathrm{PO}$, rather than being a "champion" of victims, was considered an "impartial" arbiter of crime victims" complaints (Rock, 2004, p. 553; Manikis, 2012). New Zealand followed a similar path. ${ }^{14}$ In the US, the committee structure devised to promote and enforce compliance with victims' rights legislation in Colorado reflected the state's "decentralized" service structure and existing "collaborative working relationship[s]". The Minnesota Office of the Crime Victims Ombudsman was part of a unique tradition in that state of "speciality" ombudsmen targeting "underserved populations" and overseeing specific government agencies (Office for Victims of Crime [OVC], 1998, pages 5, 18 and 27). In Alaska, an office was created by the legislature to provide "free legal services to victims of crime to help them protect their guaranteed constitutional and statutory rights with regard to their contacts with police, prosecutors, defense counsel, judges, and criminal justice agencies in the state" (Branchflower, 2004, p. 259). Federal legislators in the US and Canada also established a specific Crime Victim Ombudsman to investigate and resolve allegations of victims' rights breaches for those jurisdictions (GAO, 2008; Manikis, 2015). A review of state-sanctioned bodies in the US concluded that "although broadly categorised", the primary differences in the [compliance enforcement] programs studied relate to the investigative and sanctioning powers of the program officials; the role of the program or office as either an impartial liaison or an advocate for victims; the range of services provided; and the role of the compliance enforcement program in the

\footnotetext{
${ }^{14}$ Victims' Rights Act (New Zealand) 2002 s 10. Complaints (s49) by victims may be made to the Ombudsman, Police Conduct Authority or to the Privacy Commissioner.
} 
provision of training and outreach to the public and the criminal justice community. (OVC, 1998, p. 57). ${ }^{15}$

We build on these categories to analyze the regulatory role of Australian victims' rights commissioners. Sourcing data from public records and websites, our analysis first examines the status of the commissioners and whether they are multi-service. We then examine the commissioners' functions, divided into three areas: educative/promotional, enquiry/monitoring, and investigative and enforcement, and then examine transparency of their performance. Finally, from this analysis we sketch an exemplar victims' rights compliance regime and return to discuss the tension identified for regulators between advocacy and impartiality.

\section{Australian victims' rights commissioners}

Australia is comprised of nine jurisdictions: federal and eight states and territories. The earliest victims' rights charters were legislated in 1994 Western Australia (WA) and the Australian Capital Territory (ACT). Following those were South Australia (SA, 2001), New South Wales (NSW, 1996), Victoria (2006), Queensland (2009), Tasmania (2001) and the

\footnotetext{
${ }^{15}$ This earlier assessment of diversity of programs in the US persists. A 2017 list of 11 state crime victim compliance and enforcement programs plus the Federal Crime Victim Ombudsman shows programs located within Governor's office, within the legislature, and inside and outside government. Retrieved 27 March 2019 from https://dps.mn.gov/divisions/ojp/forms-
} documents/Documents/State\%20victim\%20rights\%20compliance\%20programs.pdf This earlier assessment of diversity of programs 
Northern Territory (NT, 2002). At a federal level, the Commonwealth of Australia adopted an administrative victims' charter in 1996.

Initially only two of the states and territories legislated for rights compliance mechanisms in their victims' charter. In the ACT a statutory office-holder, the Victims of Crime Coordinator, had authority to investigate allegations of a breach of the rights. Following an investigation, the office-holder could report findings to the Minister. ${ }^{16} \mathrm{NSW}$ required that the Victims of Crime Bureau, newly established within the Department of Justice and Attorney General, receive and resolve complaints. The NSW Victims' Rights Act specified that the rights did not give rise to any cause of action but did not preclude disciplinary action. ${ }^{17}$ Since enactment in 1994 and 1996 respectively, both statutes have changed (in 2011 and 2013 respectively) and each now establishes a Commissioner. Similarly named positions were also created in SA (2006), Victoria (2015) and WA (circa 2014). Although the WA Commissioner has responsibilities to monitor and review the criminal justice system response to victims, ${ }^{18}$ it is not included in our analysis because it has no statutory basis. ${ }^{19}$

\footnotetext{
${ }^{16}$ Victims of Crime Act (ACT) 1994 s.9 (unamended)

${ }^{17}$ Victims' Rights Act (NSW) 1996 No 114 s.11 (repealed)

${ }^{18}$ The WA Commissioner for Victims of Crime has responsibility to ensure that members of the public and government agencies are "aware" of the Victims of Crime Act 1994 and their corresponding rights and responsibilities. See,

https://department.justice.wa.gov.au/C/commissioner_for_victims_of_crime.aspx [retrieved
} 27 February 2019]

${ }^{19}$ The Acting WA Commissioner advised that as it "is not an independent office there is no requirements for specific annual reports, the commissioner makes comments in the 
Status

Four commissioners are each established in legislation. The ACT, NSW and SA legislation also sets out the standards comprising victims' rights. The Victorian Commissioner has its own enacting legislation ${ }^{20}$ separate to the Victims Charter Act 2006. The ACT Commissioner, enacted to replace the Coordinator in 2011, was also subsequently incorporated into the ACT Human Rights Commission in 2016. ${ }^{21}$ Three victims' commissioners are independent of the executive though through slightly different appointments. The SA and Victorian

Commissioners are appointed by the Governor-in-Council upon recommendation by the state Attorney General while the ACT Commissioner is appointed by the Attorney General. The NSW Commissioner, as a public servant, is not independent. An independent statutory appointment is not subject to the direction of a Minister or head of department. They may discharge their functions as they see fit subject to the usual ethical, financial and other performance requirements of the public service. A key feature of statutory independence is the authority to speak publicly without prior government approval and even critically, on topics relevant to crime victims and their treatment within criminal justice and elsewhere by government entities.

Department of Justice and previous Department of the Attorney General annual reports". Email communication, 17 January 2019.

${ }^{20}$ Victims of Crime Commissioner Act (Victoria) 2015

${ }^{21}$ Human Rights Commission Act (ACT) 2005 (amended 2016) s.12. 
Service functions

The SA, ACT and Victorian office-holders were initially enacted solely as rights-promoting entities. Over time, some have had service functions added. By service functions we mean help and assistance to individuals that are separate to oversight of the charter 'rights'. Since 2007 the ACT office-holder has progressively had added responsibility to deliver various services for victims. ${ }^{22}$ In NSW, the office-holder has always been situated in and responsible for multiple services for crime victims administered within the Department of Justice and has also had service functions added to its mandate over time. ${ }^{23}$

\section{Functions}

A division of functions into three key areas of educative/promotional, enquiry/monitoring, and investigative and enforcement shows some consistencies across the commissioners and some variation (Table 2). The distribution of functions is a "regulatory mix" (Gunningham \& Grabosky, 1998) and, for the Australian commissioners, are reasonably balanced.

INSERT TABLE 2 HERE

${ }^{22}$ The addition of functions to the independent office holder's remit are described in ACT Victims of Crime Coordinator, Victims of Crime Support Program Annual Report 2007-2008. Canberra, Department of Justice \& Community Safety.

${ }^{23}$ The NSW service framework is described at https://www.victimsservices.justice.nsw.gov.au/ [retrieved 27 February 2019] 
We have not included all statutory provisions in the analysis of commissioners' functions. Legislative language can be oblique. For example, how do we understand a function that is 'to assist victims in their dealings with prosecution authorities and other government agencies' (Victims of Crime Act SA 2001 s16(3)b); or another 'to ensure that victims receive information and assistance they need in connection with their involvement in the administration of justice' (Victims of Crime Act ACT 1994 s11(j)). These can appear passive functions. Equally, however, these could be precisely the activities that enable individual crime victims to access their rights or constitute early intervention on a victim concern about a justice agency that forestalls a potential breach or could entail an informal conciliation with a regulated entity to resolve a victim concern.

\section{Transparency}

Transparency of the commissioners' performance of their functions varies. From 2004 to 2016 the ACT office-holder published and made available online annual reports on the performance of statutory functions. ${ }^{24}$ From 2016, performance is described as a specific section alongside sections from other commissioners in the Human Rights Commission annual report. Different projects and services of the NSW Victims Services Scheme, managed by the Victims Commissioner, are reported in the NSW Department of Justice annual reports. The Victorian Commissioner publishes an annual report of which 2017-2018 is available online. ${ }^{25}$ From 2002 to 2008 , the SA office-holder reported within the annual

${ }^{24}$ Located at https://www.victimsupport.act.gov.au/who-we-are/annual-reports [retrieved 27 February 2019]

${ }^{25}$ Located at https://www.victimsofcrimecommissioner.vic.gov.au/sites/default/files/embridge_cache/emsh 
report of the Attorney General's Department with a standalone annual report made by the SA Commissioner in 2008-2009. ${ }^{26}$

Annual reports by public entities often discuss their performance in high-level language and without detail. Nonetheless, they are critical sources of information for the public and politicians. Transparency can be achieved through stand-alone reports and a scan of the websites of the Australian commissioners reveal a number. However, these tend to be on topics other than the commissioners' own functions. Any future research examining how commissioners' legislative functions have been translated on the ground in the jurisdictions and with what impact would likely use annual reports as a data source. The regulator's transparency about their activities is essential to assess effectiveness.

\section{Understanding victims' commissioners' enforcement functions and sanctions}

In a regulatory analysis, there are a number of ways to consider enforcement and sanctioning as means of behavior modification when understanding compliance as both a process and an event. Thus, we make a further distinction between commissioners' compliance functions that are reactive and narrow, and those which are proactive and broadly focused.

are/original/public/2018/09/6d/1baca1ab7/Report\%20-\%20Annual\%20Report\%20-

\%20Victims\%20of\%20Crime\%20Commissioner\%202017-18\%20.pdf [retrieved 27 February

2019]

${ }^{26}$ Sections from annual reports of the SA Attorney General's Department for years from 2002 to 2008 and the 2009 Victims Rights' Commissioner's Annual Report were sourced through the SA Parliamentary Library (22 January 2019). At s16F Victims of Crime Act (SA) 2001, specifies that, upon presentation of a report to the Attorney-General, the latter must table the report before each House of Parliament within 12 sitting days. 
Here, we return to Morgan and Yeung's categorisation of "the underlying 'modality' through which behaviour is sought to be controlled" in the regulatory regime and first focus discussion on 'command' or reactive enforcement where a specific sanction may be imposed in direct relation to a specific event following a formal investigative process. Second, we consider competition, consensus, communication, and code modalities that victims' rights commissioners may use to enforce and sanction.

\section{Command enforcement and sanctioning}

The analysis of commissioners' enforcement functions in Table 2 (right column) shows that a breach of victims' 'rights' is primarily characterized as a service complaint. Indeed, the victim charters provide that victims should first attempt to resolve the issue with the agency or official in question. Should the matter be brought to the attention of the ACT and NSW Commissioners, these are also required to attempt to "resolve" the complaint through timely early intervention. The Victorian Victims Charter Act 2006 and the SA Victims of Crime Act 2001 similarly emphasize early intervention and resolution. Only the SA Commissioner has powers approaching legal intervention. ${ }^{27}$ The Commissioner may make a submission in a proceeding (s 16(3)e) and may act as a victim representative in exercising rights to information, compensation or a sentence submission (s $32 \mathrm{~A}(3) \mathrm{b})$.

\footnotetext{
${ }^{27}$ We make this assertion in relation to a commissioner's power to intervene in criminal proceedings to protect a victim right. The ACT Commissioner is authorised to "attend" proceedings (s13) and has done so in proceedings where the accused is subject to mental health or other forensic matters.
} 
The emphasis on treating an alleged breach as a complaint is consistent with 'rights'enforcing mechanisms in the US, Canada, the UK, and New Zealand. Indeed, it is consistent with the "complaints-conciliation focus" of other Australian human rights and equal opportunity commissions (Gardner, 2008, p. 43). To emphasize the point, the Australian victims' charters specify that the 'rights' are not legally enforceable or give rise to any right to damages for breach (SA), provide no grounds for judicial review (NSW, Victoria), or other liability (Victoria).

As for the sanctioning that may occur at the end of a complaints process, two statutes (Victoria and NSW) provide that disciplinary proceedings may proceed against a relevant official. ${ }^{28} \mathrm{NSW}$, SA and Victoria provide for an apology from a public agency or official, which may be recommended by the Commissioners. ${ }^{29}$ The ACT legislation is silent about any sanction or penalty against a public agency or official. Other types of sanction such as a guarantee of non-repetition or commitment to address the substantive problem complained of, whether through enforceable or unenforceable undertakings, are absent from any of the Australian victims' charters.

Reporting publicly on complaints of a breach of rights, investigations and outcomes is another form of sanctioning, especially if reporting adverse findings. Here the commissioners' powers again vary. The SA victims' charter includes provisions concluding a complaints process. After issuing a "notice in writing" to a public agency or official recommending an apology (s 16A2), the Commissioner must provide a copy of the notice to

${ }^{28}$ Victims Charter Act (Victoria) 2006 s22(2) and Victims Rights and Support Act (NSW) 2013 Sch 2 - Cl 19 (3).

${ }^{29}$ Sections 10(1)f) in NSW and s16A(2) in SA; and Victims Charter (Vic) 2006 s19A Note. 
the relevant victim (s 16A3). Additionally, the Commissioner must report publicly in an annual report the number of notices issued and the agencies and officials to whom the notices were given (s 16A4). In 2008-2009 the Commissioner reported that, of the 159 complaints he had received, no notices were issued. He writes that he is aware of "several occasions" when an official spoke privately to a victim and of two occasions where an apology was made (SA Victims' Rights Commissioner, 2009, p. 20). The NSW Commissioner is authorized to make a "special report" to the Minister for tabling in Parliament on "any matter" (s 13(1) and "with respect to any breaches by an agency" of the victims' charter (s13(2). However, we could find no record of any special reports. For the ACT we found one report setting out a summary of 10 exemplar grievances. ${ }^{30}$ Of course, reports of investigations into individual complaints and the findings made by a commissioner and the outcomes arrived at with a regulated entity may be confidential and unavailable to the public. It may also be necessary to protect the privacy of a private citizen. At the same time, the lack of public information can undermine transparency and act to protect the reputation of a public agency or official.

In summary, the Australian victims' commissioners have sketchy, insubstantial, and limited reactive and targeted enforcement processes other than conciliation practices arising from service complaints. They also have very limited types of sanctioning powers that are usually present within 'command' compliance.

Competition, consensus, communication, and code enforcement and sanctioning

However, the broader functions of the Australian victims' commissioners offer another means to assess their enforcement and sanctioning powers. These educative and enquiry functions (Table 2, left and middle columns) have been described as "facilitation measures"

${ }^{30}$ Victims of Crime Coordinator (ACT), Annual Report 2009-1010 (pp. 10-12). 
for rights-promoting public entities (Gardner, 2008, p. 46). These may enable compliance in proactive and broad ways and require use of other institutional, social and political levers to shape and direct change. The examples we provide here derive from the websites and annual reports of the commissioners.

Competition as enforcement is easily understood in the private market when a company or service may be put out of business or wither away for poor custom. Within a public system, competition can be less clear. In the criminal justice system, where it can seem that police and prosecutors are the only defenders of the public interest, the victims' commissioners create another source of information, expertise, and perspective. They enrich and deepen the notion of public interest (Holder, 2018b). The state monopoly view that 'this is the only way to do justice' becomes contestable. However, giving this concrete effect through, for example, private prosecution is rare. One example discussed earlier, is the SA Commissioner's unique capacity, through access to a legal fund, to engage counsel to assert recognition of a particular 'right' brought forward by an individual. ${ }^{31}$ This authority creates the possibility of a direct victim voice in proceedings separate to the views presented by prosecutors. ${ }^{32}$ The various public scandals about non-prosecution that periodically erupt across the Australian states and territories have provided another avenue through which the

\footnotetext{
${ }^{31}$ The SA Victims' Rights Commissioner reports funding five matters in one year (Annual Report 2008-2009, p.19).

${ }^{32}$ Another legal intervention strategy used by victim advocates in international criminal tribunals is amicus briefs. These have been developed further for domestic courts in the US by the National Crime Victim Law Institute (Davies, et al., 2012).
} 
public prosecutor's decisions can be challenged. ${ }^{33}$ The independent victims' commissioners have all, at various times, spoken publicly (if carefully) on victims' right to seek justice. The sanctioning of a regulated entity such as the public prosecutor in a competition modality could involve, for example, having the relevant function taken away by government and reassigned or a reduction in budget.

Consensus as enforcement is also less visible. However, all the Australian victims' commissioners use a range of mechanisms to build a higher level of acceptance of the standards within victims' charters. For example, influencing and shaping preferred institutional behavior is conducted through establishing Advisory or Strategic bodies to produce, through cooperation, detailed plans and policies for the implementation of a victims' charter. The Australian commissioners also build consensus within regulated entities to comply with victims' standards through professional briefings, training, and other educational sessions for officials. Sanctioning within consensus approaches to compliance is about shaping practice in deliberate and purposeful ways, emphasizing what is preferred behavior and what is not preferred. Social consensus for compliance standards beyond the institutions is also nurtured through the informational sessions and publications that the commissioners produce.

\footnotetext{
${ }^{33}$ The public scandals are too numerous to list. Some have resulted in governmental inquiries. For example, Crime and Misconduct Commission 2003 (Queensland), Kourakis 2004 (SA), and Samuels 2002 (NSW). The Australian Royal Commission into Institutional Responses to Child Sexual Abuse is a recent example of a major systematic review of extensive and long-standing system failures with regard to victims (2017).
} 
Communication is not commonly discussed as an enforcement strategy but is one of the most powerful. A victims' commissioner communicating directly to the public (and politicians) via the media about a persisting area of concern or a non-compliant agency is enforcement and sanction in one. The commissioners may communicate the poor performance of regulated entities with charter standards in special reports or in special enquiries such as those conducted by law reform commissions. ${ }^{34}$ It is to these enquiries that commissioners may make submissions documenting the extent of complaints and concerns that victims have brought to them. Other communication strategies are "information gathering" and monitoring. The compilation of victims' grievances, the conduct of agency audits, own motion reviews, or the commissioning of research and evaluation are all activities coming within commissioners' educative, promotional, advocacy, enquiry, and reporting functions. Communication through accountability channels via annual reports, submissions to parliamentary inquiries, and reports of findings on individual or systemic concerns represent formal ways of identifying and combatting systematic injustice and chronic institutional failings to treat victims by the enacted standards. From these communication activities sanctioning can be the decisions of government or parliament to approve one program over another or to institute a new strategy to address the injustice.

Code or design approaches to compliance fall within the rights-promoting and advocacy functions of commissioners. Design compliance can 'nudge' officials to perform their functions in particular ways. Some are obvious, such as the installation of closed-circuit television and other communication aids at court for victim-witnesses, and others are less so. The commissioners have contributed to the re-design of forms and database modules that

\footnotetext{
${ }^{34}$ For example, the Victorian Law Reform Commission enquiry into The Role of Victims of Crime in the Criminal Trial Process: Report (2016) and fn30.
} 
record details of cases reported by victims to authorities. It may sound simple, but if the names and addresses individuals as victim are not recorded in institutions' informationgathering, then they will literally not be part of a case (Douglas \& Laster, 1994). Sanctioning in design approaches to compliance can also involve restriction. For example, prior practice that undermined the standards in a victims' charter, such as, the routine inclusion of a victim's address on a public court document that effectively breached a victim's privacy, can be eliminated by introducing a new document template without that inclusion.

\section{Discussion: regulating victims' rights in criminal justice}

Regulating the conduct of public functions and the performance of public officials is an accepted feature of governance in advanced liberal democracies. The regulation of criminal justice institutions introduces particular challenges however. Its institutions defend their independence (Cowdery, 1995). While the criminal justice system provides services, it is primarily established to investigate, prosecute and adjudicate alleged breaches of the criminal law. A criminal justice 'case' involves a number of individual citizens, the accused, victim, or witness, plus professionals each with particular interests. Therefore, rather than a single regulatory framework, criminal justice carries a range of inter-connecting regulatory instruments; one of which is a victims' rights charter. For victims' rights, this context requires a skilled specialist regulator, willingness on the part of the regulated entities to engage constructively, and a shared commitment to realizing the public good envisaged by the legislature (Black, 1997).

A victims' rights regulator may perform all her activities only in this manner. Indeed, a 'soft' regulator, established as part of government bureaucracy, may be restricted to these educative and promotional functions. A 'harder' victim rights regulator secures independence from 
government in a founding statute. Further, a 'hard' regulator will have enforcement powers however sparingly used. In this categorization of soft to hard regulators, statutory enactment has a number of benefits: it makes plain the design features, functions and powers of a victims' regulator; it situates the victim constituency within the broader public interest; places ethical and performance obligations on the regulator similar to other public entities; provides political and structural authority to the regulator; and can make more difficult any attempts to undermine or abolish a victims' regulator. Our Australian case study has examined a particular regulatory form of statutory public-interest commissioners. However, our analysis makes more transparent the design choices that governments elsewhere could make for a rights watchdog.

We have also discussed compliance as a creature of design and function; a mix of formal and informal practice, and both process and event. In analysing enforcement and sanctioning approaches from five underlying modalities in regulation, we have moved beyond the usual categorising of victims' rights enforcement as either administrative or legal. Instead we have showed compliance and enforcement as two sides of one coin and comprising reactive and proactive elements. However, our analysis also shows gaps in the design of specialist victims' rights regulators in Australia and patchy or limited regulatory powers that are likely found in others such as the UK victims commissioner. ${ }^{35}$ Victims' rights regulators, working with government legislators, could develop a more systematic approach to their work producing compliance in regulated entities with the victim charters. For this objective, we offer a victims' charter compliance pyramid (Figure 3) that builds and communicates social consensus for rights at its base and moves to command enforcement through use of notices

\footnotetext{
${ }^{35}$ Established in 2010 as the Commissioner for Victims and Witnesses in the Domestic
} Violence, Crime and Victims Act 2004 s48. 
and undertakings. These latter sanctions could require a regulated entity such as the public prosecutor to, for example, implement routine measures to protect victim privacy or to consistently require consultation of victims by prosecutors. Some other targeted compliance activities, such as undertakings and amicus briefs, are currently available in the barest forms in the jurisdictions we studied. However, their use in other rights-protecting areas suggest considerable scope for future development. ${ }^{36}$

\section{INSERT FIG 3 HERE}

Our victims' rights compliance pyramid can be read in two ways. First, as a depiction of a regulatory strategy it shows how government in any given jurisdiction, working with the three parties of regulators, regulated entities and victim representatives, can put in place graduated levels of activity to implement victims' rights charters. Second, it can be read as an exemplar design of the functions and powers for a victims' rights regulator. On both readings, an exemplar victims' compliance pyramid shows that the choices of regulatory instrument and tools that are made by governments and regulators can result in the strong regulation of victims' rights or weak regulation. An effective regulator requires the right functions, specification of compliance processes, a range of enforcement powers, and the resources to do the job.

\footnotetext{
${ }^{36}$ For example, amicus briefs are used extensively in the US by the National Crime Victim Law Institute (see https://law.lclark.edu/centers/national_crime_victim_law_institute/projects/legal_advocacy/ retrieved 25 November 2019) and in international criminal tribunals (Williams, Woolaver \&
} Palmer, forthcoming 2020) 
Figure 3: Victims' rights compliance pyramid (adapted from Ayres \& Braithwaite, 1992 and Gardner, 2008, p. 45)

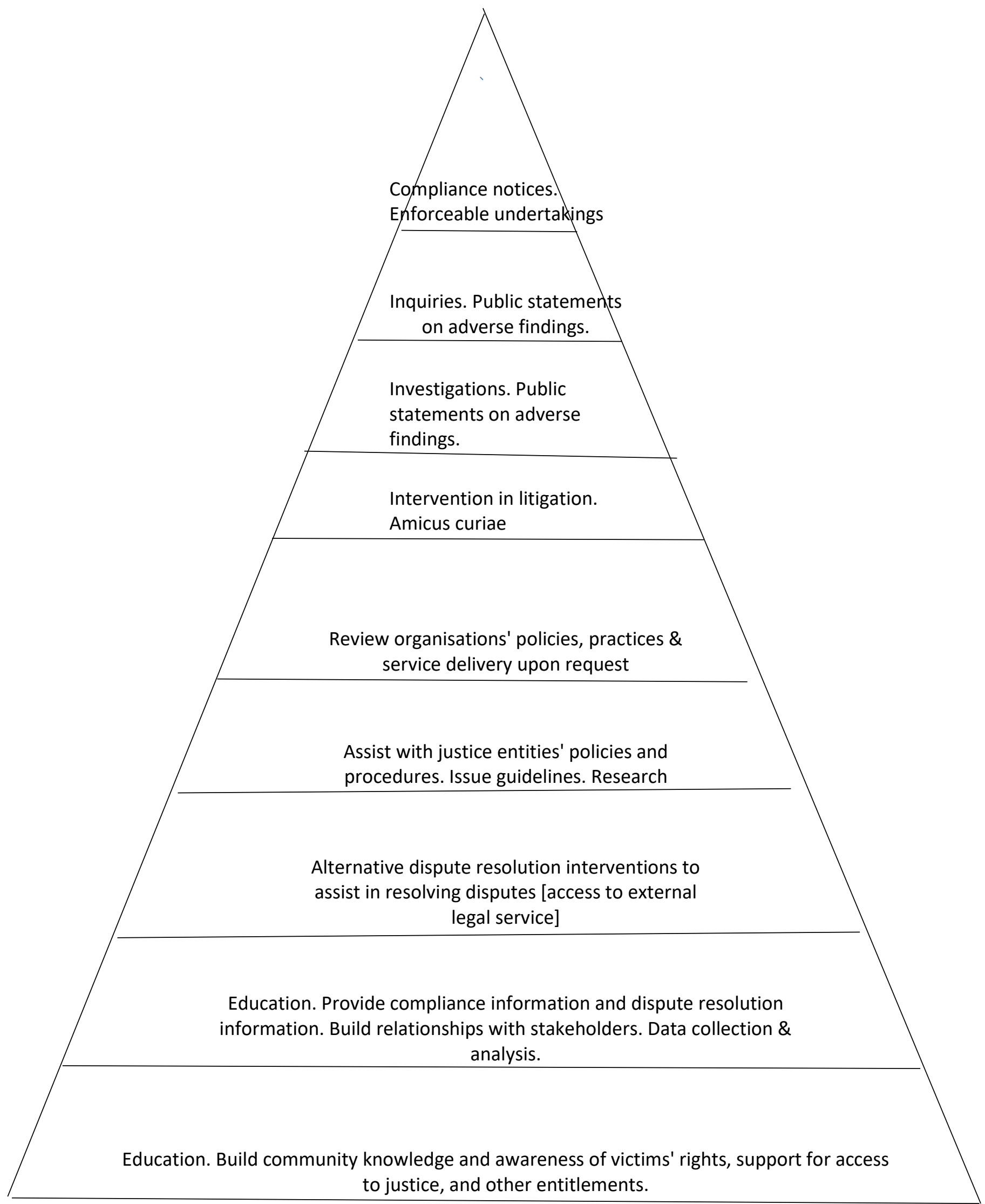


Our analysis of the regulatory regime for victims' rights in Australia has revealed these as less than our exemplar, albeit with highlights. The non-command enforcement and sanctioning approaches to compliance with victims' charters at the base of the pyramid are those mostly used by victims' commissioners. These can appear weakly indirect.

Governments are adept at setting symbolic policy goals such as bringing victims "to the heart of criminal justice" (Jackson, 2003). They are also renowned for under-resourcing regulatory bodies (Smith, 2006). Thus, a regulator that emphasizes a proactive and broad compliance strategy to victims' rights may simply reflect a power imbalance with the regulated entities of criminal justice. A conciliatory approach can operate as "a means of sustaining the consent of the regulated where there is ambivalence about the enforcement agency's mandate" (Hawkins, 1984 cited in Morgan and Yeung, 2007, p. 186). Gaming the regulator, here a victims' commissioner, preserves the business of criminal justice for known and more powerful state players.

Nonetheless influencing criminal justice to achieve the institutional and behavioural changes necessary for practical recognition, inclusion and fairness for crime victims is "a real challenge”. Our victims' compliance pyramid brings strategic robustness to this challenge. While victims' rights' regulators may presently sit at the periphery of the criminal justice system, simultaneously removing and containing victims in an administrative space, they also work to constructively connect victims to the police, prosecutions, and the courts. In doing so the Australian victims' commissioners act as a bridge, a translator, a guide, and as an advocate for crime victims in a highly complex technical system. On a day-to-day basis, this may be how rights-promotion and rights-protection works. It is, said one commissioner, “difficult to differentiate a victims' request for advocacy and a victim's grievance or complaint" (SA Commissioner, 2009, p. 20). A fluid and negotiable approach to compliance 
that seeks positive outcomes for individual victims and victims as a constituency requires specialist knowledge and skill on the part of the regulator.

These regulatory practices raise a question over the role that advocacy plays for a rightsprotecting and rights-promoting victims' regulator and the tension it creates with the complaints' management function (Rock, 2004, p. 553; OVC, 1998). This tension is a feature of other rights-protecting entities such as human rights commissions (Gardner, 2008, p. 43). Future research could shed light on the circumstances in which rights regulators deploy these functions: do they come from a position of strength or weakness, what other factors are at play? The informality of the practices needs a high degree of specification and transparency for parties in the regulatory regime otherwise there can be accusations of "capture", of "game playing”, or of the regulator's submission before a more powerful entity (Ayres \& Braithwaite, 1992). The discretion upon which informal practice rests always require a delicate, though deliberate, balancing between achieving outcomes and transparency and consistency. Ultimately, such discretion - offering 'gentle' pathways to compliance requires at least the possibility of 'a big stick', especially in an environment of monopoly state power as in criminal justice. An effective victims' rights regulator may choose to use a big stick infrequently and with strategic intent, but it should be available.

\section{Conclusion}

Crime victims are a diverse constituency and their preparedness to cooperate with criminal justice entities in the investigation and prosecution of crime has been taken for granted. Victims' charters are one means whereby governments have attempted to set standards for the fair and proper treatment of individuals and groups of victims in the administration of justice. To date, researchers have focused on the availability to victims themselves of effective complaint or rights enforcement processes. Our regulatory analysis has widened the 
lens to take account of a broader range of instruments, tools, and strategies available for victims' rights compliance. A next step is to locate information on regulators' activities in order to assess the effectiveness of compliance strategies. In this endeavour, regulatory analysis provides more precise terminology with which to analyse the role of specialist regulators such as statutory victims' commissioners. A regulatory analysis de-constructs the design of the regulatory regime for victims' rights. This then provides a clearer picture of the duties of regulated entities to properly implement victims' rights, and sharper definition of their accountabilities in doing so. 
Table 1: Mode and techniques through which regulation is directed, and victim charter examples

\begin{tabular}{|c|c|c|c|c|}
\hline Category & Form & Strategy & Tools & Victims' charter examples \\
\hline Competition & Market & $\begin{array}{l}\text { Harness rivalry } \\
\text { (internal or external } \\
\text { 'like' units) }\end{array}$ & $\begin{array}{l}\text { Incentives/subsidies } \\
\text { Charges } \\
\text { Liabilities }\end{array}$ & $\begin{array}{l}\text { Victim-centred agencies/services } \\
\text { as new source of expertise/ } \\
\text { authority } \\
\text { Increased resources for charter } \\
\text { functions } \\
\text { Enabling third parties (eg private }\end{array}$ \\
\hline
\end{tabular}




\begin{tabular}{|c|c|c|c|c|}
\hline & & & & prosecution, private security) \\
\hline Consensus & $\begin{array}{l}\text { Self-regulation } \\
\text { Social consensus }\end{array}$ & $\begin{array}{l}\text { Cooperation } \\
\text { Consent-based } \\
\text { Contract }\end{array}$ & $\begin{array}{l}\text { Professional rules } \\
\text { Contracting (formal/informal) } \\
\text { Protocols \& guidelines }\end{array}$ & $\begin{array}{l}\text { Code of Practice } \\
\text { Inter-agency agreement } \\
\text { Agency policies, performance } \\
\text { targets, and service standards }\end{array}$ \\
\hline Communication & $\begin{array}{l}\text { Indirect social } \\
\text { pressure }\end{array}$ & $\begin{array}{l}\text { Negotiation } \\
\text { Persuasion } \\
\text { Education }\end{array}$ & $\begin{array}{l}\text { Inform target audience } \\
\text { Public education for consumers } \\
\text { Media } \\
\text { Research \& monitoring } \\
\text { Reporting (mandated or voluntary } \\
\text { disclosure) } \\
\text { Bilateral/multi-lateral partnerships }\end{array}$ & $\begin{array}{l}\text { Information briefings about } \\
\text { victim-relevant topics } \\
\text { Professional training } \\
\text { Consumer information about their } \\
\text { rights } \\
\text { Research, evaluation, audit } \\
\text { Annual reports including } \\
\text { performance on meeting victim } \\
\text { charter standards } \\
\text { Victim Advisory Council/ Board } \\
\text { Criminal justice/victim agency }\end{array}$ \\
\hline
\end{tabular}




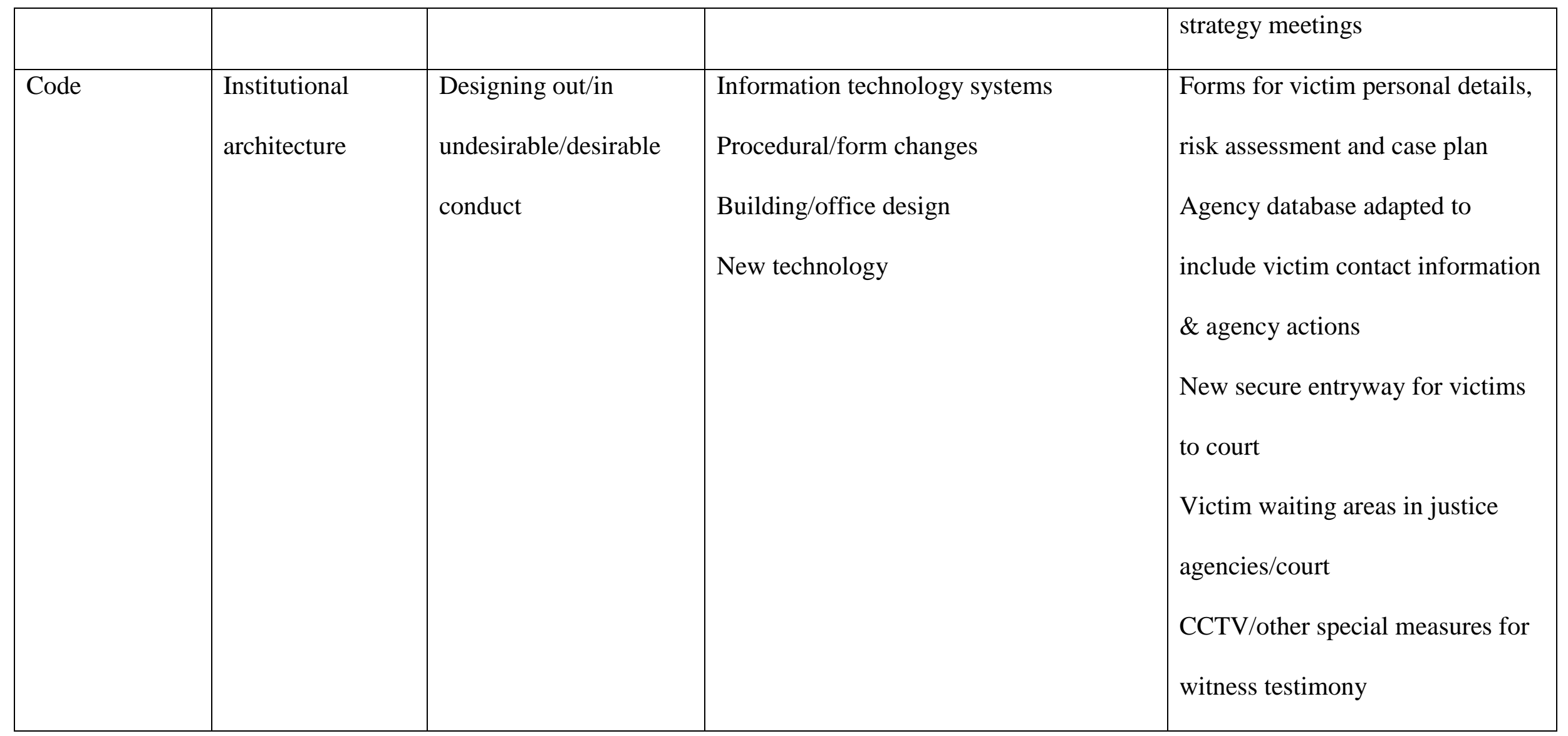

SOURCE: Categorisation from Morgan \& Yeung (2007) and authors' work 
Table 2: Australian Victims’ Rights Commissioners Functions

\begin{tabular}{|c|c|c|c|}
\hline Juris & Educative/Promotional Functions & Enquiry/Monitory Functions & $\begin{array}{l}\text { Investigative \& Enforcement } \\
\text { Functions }\end{array}$ \\
\hline $\mathrm{ACT}^{37}$ & $\begin{array}{l}\text { Develop educational and other } \\
\text { programs to promote awareness of } \\
\text { the interests of victims (s11(h)) } \\
\text { Distribute information about the } \\
\text { operation of this Act and the } \\
\text { commissioner's functions (s11(i)) }\end{array}$ & $\begin{array}{l}\text { Monitor and promote compliance with } \\
\text { the governing principles (s11(d)) } \\
\text { Consult on and promote reforms to } \\
\text { meet the interests of victims (s11(g)) } \\
\text { Encourage and facilitate cooperation } \\
\text { between agencies involved in the } \\
\text { administration of justice with respect } \\
\text { to victims (s11(k)) } \\
\text { Advise the Minister on matters } \\
\text { relating to the interests of victims } \\
\text { (s11(l)) }\end{array}$ & $\begin{array}{l}\text { Advocate for the interests of victims } \\
\text { (s11(b)) } \\
\text { Advocate for the interests of affected } \\
\text { people under the Mental Health Act } \\
2015 \text { (s11(c)) } \\
\text { Ensure concerns and formal complaints } \\
\text { about non-compliance with the } \\
\text { governing principles are dealt with } \\
\text { promptly and effectively (s11(e)) } \\
\text { The commissioner must try to resolve } \\
\text { any concern raised with the }\end{array}$ \\
\hline
\end{tabular}

${ }^{37}$ Victims of Crime Act (ACT) 1994 (amended) 


\begin{tabular}{|c|c|c|c|}
\hline & & & $\begin{array}{l}\text { commissioner by a victim about non- } \\
\text { compliance with the governing } \\
\text { principles by an agency involved in the } \\
\text { administration of justice (s12(1)) }\end{array}$ \\
\hline $\mathrm{NSW}^{38}$ & $\begin{array}{l}\text { Promote and oversee the } \\
\text { implementation of the Charter of } \\
\text { Victims' Rights, including by } \\
\text { publishing codes, guidelines and } \\
\text { other practical guidance on the } \\
\text { implementation of the Charter } \\
\text { (s10(1)c) } \\
\text { Conduct, promote and monitor } \\
\text { training, public awareness activities }\end{array}$ & $\begin{array}{l}\text { Make recommendations to assist } \\
\text { agencies to improve their compliance } \\
\text { with the Charter of Victims' Rights, } \\
\text { including but not limited to conducting } \\
\text { training and recommending changes to } \\
\text { policies and procedures (s10(1)d) } \\
\text { Conduct reviews and inquiries, or } \\
\text { both, on issues relating to victims of } \\
\text { crime at the request of the Attorney }\end{array}$ & $\begin{array}{l}\text { Receive complaints from victims of } \\
\text { crime (and members of the immediate } \\
\text { family of missing persons) about } \\
\text { alleged breaches of the Charter of } \\
\text { Victims' Rights and to use the } \\
\text { Commissioner's best endeavours to } \\
\text { resolve the complaints (s10(1)e) } \\
\text { Recommend that agencies apologise to } \\
\text { victims of crime for breaches of the }\end{array}$ \\
\hline
\end{tabular}

${ }^{38}$ Victims' Rights and Support Act (NSW) 2013 


\begin{tabular}{|c|c|c|c|}
\hline & $\begin{array}{l}\text { and research on victims of crime } \\
(\mathrm{s} 10(1) \mathrm{g})\end{array}$ & General (s10(1)h) & Charter of Victims' Rights (s10(1)f) \\
\hline $\mathrm{SA}^{39}$ & & $\begin{array}{l}\text { Marshal available government } \\
\text { resources so they can be applied for } \\
\text { the benefit of victims in the most } \\
\text { efficient and effective way (s16(3)a) } \\
\text { Monitor and review the effect of the } \\
\text { law and of court practices and } \\
\text { procedures on victims (s16(3)c) }\end{array}$ & $\begin{array}{l}\text { Make submissions in any proceedings- } \\
\text { to make such submissions (either } \\
\text { personally or through counsel) (s16(3)e) }\end{array}$ \\
\hline Victoria $^{40}$ & Advocate for the recognition, & Carry out inquiries on systemic victim & Report to the Attorney-General on any \\
\hline
\end{tabular}

\footnotetext{
${ }^{39}$ Victims of Crime Act (SA) 2001

${ }^{40}$ Victims of Crime Commissioner Act (Vic) 2015
} 


\begin{tabular}{|l|l|l|l|}
\hline $\begin{array}{l}\text { inclusion, participation and respect } \\
\text { of victims of crime (s13(1)a) }\end{array}$ & $\begin{array}{l}\text { of crime matters (s13(1)b) } \\
\text { Provide advice to the Attorney- } \\
\text { General and government departments } \\
\text { and agencies regarding improvements }\end{array}$ & $\begin{array}{l}\text { May review an agency's response to a } \\
\text { (s13(1)c) } \\
\text { to the justice system to meet the needs } \\
\text { victim complaint } \\
\text { of victims of crime (s13(1)d) }\end{array}$ & \\
& & \\
\end{tabular}




\section{References}

Ayres, I. \& Braithwaite, J. (1992). Responsive regulation: Transcending the deregulation debate. Oxford, UK: Oxford University Press.

Bardach, E. \& Kagan, R. (1982). Going by the book: The problem of regulatory unreasonableness. Philadelphia, PN: Temple University Press.

Beloof, D.E., 2005. Third wave of crime victims' rights: standing, remedy, and review. The Brigham Young University Law Review, 2, 255-370.

Black, J. (1997). Rules and regulators. Oxford, UK: Clarendon Press

Bodenhamer, D. (2008). Fair trial: Rights of the accused in American history. OUP USA.

Bourdieu, P. (1987). The force of law: towards a sociology of the juridicial field. The Hastings Law Journal, 38, 814-853.

Brienen \& Hoegen, (2000). Victims of crime in 22 European criminal justice systems. WODC, KU Brabant: Wolf Legal Productions.

Bronitt, S. \& McSherry, B. (2017). Principles of criminal law (4 ${ }^{\text {th }}$ ed.). Sydney, Australia: Thomson Reuters, Lawbook Company,

Buzawa, E. and Buzawa, C. (2003). Domestic violence: The criminal justice response. Thousand Oaks, CA: Sage.

Cardenas, J. (1986). Crime victim in the prosecutorial process. Harvard Journal of Law and Public Policy 9(2), 357-398.

Chang, L. \& Brewer, R. (Eds.) (2018). Criminal justice and regulation revisited: Essays in honour of Peter Grabosky. London, UK: Routledge. 
Commonwealth Secretariat (2007). Comparative Study on Mandates of National Human Rights Institutions in the Commonwealth. London, UK: Commonwealth Secretariat.

Cowdery, N. (1995). Hot seat or Siberia. Journal of the NSW Bar Association, 5-8.

Crime and Misconduct Commission [CMC]. (March 2003). The Volkers Case: Examining the Conduct of the Police and Prosecution. Brisbane, Australia: CMC.

Davies, J. \& Lyon, E. (2014). Domestic violence advocacy: Complex lives/difficult choices ( $2^{\text {nd }}$ ed.). Thousand Oaks, CA: Sage.

Davis, R. \& Mulford, C. (2008). Victim rights and new remedies: finally getting victims their due. Journal of Contemporary Criminal Justice, 24 (2), 198-208.

Davis, R., Anderson, J., Howley, S., Dorris, C. \& Whitman, J. (2012). No more rights without remedies: An impact evaluation of the NCVLI Victims' Rights Clinics. RAND.

Doak, J., (2008). Victims' rights, human rights and criminal justice: reconceiving the role of third parties. Portland, OR: Hart Publishing.

Doak, J., Henham, R. \& Mitchell, B. (2009). Victims and the sentencing process: Developing participatory rights? Legal Studies 29(4), 651-677.

Douglas, R. \& Laster, K. (1994). Victim information and the criminal justice system: adversarial or technocractic reform? La Trobe University, Victoria.

Drahos, P. (Ed.) (2017). Regulatory theory: Foundations and applications, Canberra, Australia: ANU Press.

Emmerson, B., Ashworth, A., Macdonald, A., Choo, A. \& Summers, M. (2012). Human rights and criminal justice ( $3^{\text {rd }}$ Ed.). London, UK: Sweet \& Maxwell. 
Englebrecht, Mason, Adams, (2014). The experiences of homicide victims' families with the criminal justice system: An exploratory study. Violence and Victims, 29(3), 407421

Fundamental Rights Agency [FRA] (2019). Victims' rights as standards of criminal justice: Justice for victims of violent crime. Part I. Vienna, Austria: European Union Agency for Fundamental Rights.

Gardner, J. (2008). An Equality Act for a fairer Victoria: Equal opportunity review final report. Melbourne, Australia: Department of Justice.

Government Accountability Office [GAO] (2008). Crime Victims’ Rights Act: Increasing awareness, modifying the complaint process, and enhancing compliance monitoring will improve implementation of the Act. Report to Congressional Committees. Washington, GAO.

Grabosky, P. \& Braithwaite, J. (1986). Of manners gentle: Enforcement strategies of Australian business regulatory agencies. Oxford, UK: Oxford University Press.

Groenhuijsen, M. (2005). International Protocols on Victims' Rights and some Reflections on Significant Recent Developments in Victimology. Paper presented to the XIth International Symposium on Victimology, Stellenbosch, South Africa (2003).

Groenhuijsen, M. \& Pemberton, A. (2009). The EU Framework Decision for victims of crime: Does hard law make a difference? European Journal of Crime, Criminal Law and Criminal Justice, 17(1), 43-59.

Gunningham, N. \& Grabosky, P. (1998). Smart regulation: Designing environmental policy. Oxford, UK: Oxford University Press.

Hancher L. \& Moran, M. (1989). Organizing regulatory space. In L. Hancher \& M. Moran (Eds.). Capitalism, culture, and regulation. Oxford, UK: Clarendon Press. 
Hetherington, T. (1989). Prosecution and the public interest. London, UK: Pergamon Press.

Hillenbrand, S. \& Smith, B. (1989). Victims' rights legislation: An assessment of its impact on criminal justice practitioners and victims. Washington, DC: American Bar Association, Criminal Justice Section.

Holder, (2008). The quality of justice. Operation of the Victims of Crime Act 1994 in the Australian Capital Territory, 1994-2007. Canberra, Australia: Victims of Crime Coordinator.

Holder, R. (2018a). Decoding hegemony: Exploring the discourse of a prosecuting elite. In V. Colvin \& P. Stenning (Eds.), The evolving role of the public prosecutor: Challenges and innovations. London, UK: Routledge.

Holder, R. (2018b). Just interests: Victims, citizens and the potential for justice. Cheltenham, UK: Edward Elgar.

Hood, C., Rothstein, H. \& Baldwin, R. (2001). The government of risk. Oxford, UK: Oxford University Press.

Hutter, B. (1997). Compliance, regulation and environment. Oxford, UK: Clarendon Press.

Jackson, J. (2003). Justice for all: Putting victims at the heart of criminal justice? Journal of Law and Society, 30(2), 309-337.

Kilpatrick, D., Beatty, D. \& Howley, S. (1998). The rights of crime victims: Does legal protection make a difference? Research in Brief. National Institute of Justice. Washington, DC: US Department of Justice.

Kirchengast, T. (2006). The victim in criminal law and justice. Houndmills, UK: Palgrave Macmillan. 
Kirchengast, T. (2016a). Victims and the criminal trial. Houndmills, UK: Palgrave Macmillan.

Kirchengast, T. (2016b). Enforceable rights for victims of crime in adversarial justice. Revista de Victimologia / Journal of Victimology, 3, 11-42

Kirchengast, T. (2017). Victimology and victim rights: International comparative perspectives. Oxon: Routledge.

Kourakis, C. (2004). Request to advise on Matter of Paul Nemer and associated issues. Adelaide, Australia: Government of South Australia.

Langbein, J. (2003). The origins of the adversary criminal trial. Oxford, UK: Oxford University Press.

Laxminarayan, M., Bosman, M., Porter, R. \& Sosa, L. (2013). Victim satisfaction with criminal justice: A systematic review. Victims \& Offenders, 8(2), 119-147.

Manikis, M. (2012). Navigating through an obstacle course: The complaints mechanism for victims of crime in England and Wales. Criminology and Criminal Justice, 12(2), 149173.

Morgan, B. \& Yeung, K. (2007). An introduction to law and regulation. Cambridge, UK: Cambridge University Press.

Office for Victims of Crime [OVC], (1998). Victims' rights compliance efforts: Experience in three states. OVC Report. US Department of Justice.

Ogus, A. (2004). Regulation: Legal form and economic theory. Oxford, UK: Hart Publishing. 
Parker, C \& Braithwaite, J. (2003). Regulation. In P. Cane \& M. Tushnet (Eds.), The Oxford Handbook of Legal Studies (pp. 119-45). Oxford, UK: Oxford University Press.

Rock, P. (1990). Helping victims of crime: The Home Office and the rise of Victim Support in England and Wales. Oxford, UK: Oxford University Press.

Rock, P. (2004). Victims, prosecutors and the state in nineteenth century England and Wales. Criminal Justice, 4(4), 331-354.

Rock, P., (2004). Constructing victims' rights: The Home Office, New Labour, and victims. Oxford, UK: Oxford University Press.

Royal Commission into Institutional Responses to Child Sexual Abuse [RCIRCSA]. 2017. Criminal Justice Report. Parts I-X. Sydney: Commonwealth of Australia.

Samuels G. (2002). Review of the New South Wales Director of Public Prosecutions' Policy and Guidelines for Charge Bargaining and Tendering of Agreed Facts: Report. Sydney, Australia: NSW Government.

Sen, A. (2009). The idea of justice. Cambridge, MA: The Belknap Press of Harvard University Press.

Shapland, J., 2000. Victims and criminal justice: creating responsible criminal justice agencies. In A. Crawford and J. Goodey (Eds.), Integrating a victim perspective within criminal justice: international debates (pp 147-164). Dartmouth, UK: Ashgate.

Shapland, J., Willmore, J. and Duff, P., 1985. Victims in the criminal justice system. Aldershot: Gower Publishing.

Smith, B. (2006). Regulatory analysis of the Sex Discrimination Act 1984 (Cth): Can it effect equality or only redress harm? In C. Arup, et al. (Eds.), Labour law and labour 
market regulation: Essays on the construction, constitution and regulation of labour markets and work relationships (pp 105-124). Sydney, Australia: Federation Press.

Stenning, P. (1986). Appearing for the Crown: A legal and historical review of criminal prosecutorial authority in Canada. Cowansville, PQ: Brown Legal Publications Inc.

Thomas, R. (2000). Legitimate expectations and proportionality in administrative law. Oxford, UK: Hart Publishing.

Uhrig, J. (2003). Review of corporate governance of statutory authorities and office holders. Canberra, Australia: Commonwealth of Australia.

Victorian Law Reform Commission [VLRC] (2016). The role of victims of crime in the criminal trial process: Report. Melbourne, Australia: VLRC.

Whitehead, E. (2001). Witness satisfaction: findings from the Witness Satisfaction Survey, 2000. Home Office Research Study No. 230. London, UK: Home Office.

Williams, S., Woolaver, H. \& Palmer, E. (forthcoming 2020). The amicus curiae in international criminal justice. London, UK: Hart Publishing.

Wolf, G. (2017). Regulating health professionals. In A. Farrell, J. Devereux, I. Karpin, \& P. Weller (Eds.), Health law: Frameworks and context (pp.73-99). Cambridge, UK: Cambridge University Press.

Woods, G. (2002). A history of the criminal law in New South Wales: The colonial period 1798-1900. Sydney, Australia: The Federation Press. 